\title{
GLOBALIZATION OF ENERGY MARKETS: PROSPECTS OF ENERGY INTEGRATION IN EAST ASIA
}

\author{
Yana Mishchenko
}

The economic integration is a widely known and widespread process in the global economy. Integration in energy sphere is quite a new process which only nowadays is becoming achievable through both coordination of energy policies between certain countries and highly advanced energy technologies. The article is devoted to the urgent issues of energy integration developments in East Asia. It uses the representative selection of the following countries: Japan, China, South Korea, and ten ASEAN member states. Special attention is given to intergovernmental initiatives on energy ties development. Basing on the conducted analysis an attempt to estimate prospects of energy integration between the ASEAN member states and further involvement of Japan, China, and South Korea in this process is made.

Keywords: integration, energy, East Asia, ASEAN, South East Asia.

The majority of the East Asian states are net importers of hydrocarbons which fact increases their dependence on energy imports. According to some forecasts, this region along with economic growth and maintenance as an additional world economic center will run an energy deficit in the twenty-first century. Already today the countries compete for access to the world energy sources. However, there is not only the competition in the region but also a trend for cooperation in the energy field. This is partially due to the currently complicated circumstances and problems, and emerging challenges in the sphere of energy so that more often joint efforts of interested parties are needed for regulation. Besides, such states as Japan see opportunities for improving forecasting process in energy and therefore its stabilization in enhancing the relations with neighbouring countries. At the background of general integration in East Asia which, according to many experts, is in progress, it is especially interesting and important to study the possibilities of integration between the countries and certain groups of countries in the energy field. The research and analysis of this question are utterly significant and of vital importance regarding the current developments of the energy situation in East Asia.

\section{Literature Review}

Given the keen urgency of the topic, the energy cooperation in East Asia has already become the subject of study by experts throughout the world. Thus, the scientists of the Economic Research Institute for ASEAN and East Asia (Han Phoumin, Fukunari Kimura, Youngho Chang, Tri Widodo, Yanfei Li, Chea Piseth, Chea Sophearin, Yanrui Wu, Dandan Zhang, Xunpeng Shi, Yu Sheng, Romeo Pacudan, Dayong Zhang, Anin-

Journal of Globalization Studies, Vol. 9 No. 2, November 2018 50-62

DOI: $10.30884 / j o g s / 2018.02 .04$ 
dya and Tania Bhattacharya, David C. Broadstock, and some others) has been conducting the energy markets integration studies for several years, and these studies have been promoted by East Asia governments to deepen their understanding of matters affecting the energy trade liberalization and investment, energy infrastructure, pricing reform, and deregulation of domestic energy markets. Some studies of energy markets integration focused on the review of the regional commitment of East Asian Summit countries, the benefits from such integration, the electricity market, theories, subsidies, and renewable energy (Kimura and Han 2014: 1-2).

In some publications, the Russian scholars suggest that energy integration in East Asia is possible mainly among the three huge economies of the region (Japan, China, and South Korea) with further involvement of the more developed and ready for this process states of ASEAN (Miheev 2007: 60). This viewpoint undoubtedly has certain a reasonable background and reasons, but the fact is that the energy situation in the twenty-first century is particularly subject to a rapid change and dynamic progress while the realities can change both gradually and drastically. In the present paper I am going to study the current situation and key forms of energy cooperation in South East Asia to show that without close participation of the three energy giants of East Asia - Japan, China, and South Korea - the energy integration in the region is still viable and highly possible. Moreover, it can further involve North East Asia states as well. So, the author's hypothesis is that energy integration in East Asia can develop not only on the base of Japan, China or South Korea - that it is already viable and feasible in South East Asia, and it will make the novelty of the conducted research.

In this paper, we will study the present circumstances and key forms of energy cooperation in East Asia using the representative selection of the above-mentioned countries of the region in order to analyze the feasibility and prospects of formation of a common energy space in the East Asian region, or within its certain area.

\section{Energy Resources Trade in East Asia}

The ASEAN states are relatively equally divided into net exporters and net importers of energy resources. This fact allows a conclusion about the already existing preconditions for energy trade within the region and complementarity factors of the ASEAN states' energy markets. Japan, China, and South Korea are net importers of energy, and while China can at least partly meet its huge energy needs at the expense of domestic energy resources, Japan and South Korea are almost entirely dependent on energy imports. Their energy consumption is huge and among the ASEAN countries Malaysia, Indonesia, and Brunei supply energy (mainly LNG and some types of processed energy products) for them. However, one should note that their importance in this role is due not so much to the amount of provided energy, but to the significance for Japan and South Korea of the idea of sustaining stable economic ties with its neighbour countries in East Asia.

An important aspect of trade in energy sphere of the countries under study is its complex and multilevel structure, interconnections in supply chains and various endogenous and exogenous factors influencing them For instance, the fact that 'energyhungry' Japan and South Korea import hydrocarbons from Brunei seems logical and reasonable, but among the countries purchasing the Bruneian oil one can also find In- 
donesia which is among the countries - net exporters of energy resources and some time ago used to be a member of the Organization of the Petroleum Exporting Countries (OPEC). The similar situation in observed with Malaysia: more than 7 per cent of its produced oil is exported, mainly to Japan and the US, but at the same time Malaysia imports significant amouns of crude oil from the Middle East. This can be explained by the fact that the Malaysian oil is more expensive (since its chemical structure contains a lower percentage of sulphur) in comparison with the Middle Eastern oil. Another reason is that oil refinery plants operating in Malaysia are oriented technologically more to refining mainly Middle Eastern oil. To some extent, this situation may be considered an illustration of the theory of comparative advantage in international trade, which indicates the complementarity of energy sectors of the countries within the East Asian region (Mishchenko 2012: 29-36).

Singapore does not have crude oil reserves but it managed to become one of the major oil refining hubs and an important oil trading center in the region. Since the 1960s the country has been constructing refineries. Refinery capacity and oil products show the importance of Singapore in the world oil market. Singapore, as an oil refining hub in Asia, imports crude oil from Middle Eastern countries and exports oil products. As of 2008, the largest volume of oil products was exported to Hong Kong, followed by Malaysia. China and Japan are among the top-10 largest importing countries. Singapore also imports crude oil from Vietnam and the Philippines and exports oil products to the two countries (Youngho Chang 2014: 19-20).

In 2017 Singapore's crude oil imports amounted 53.7 million tonnes, oil products imports -128.5 million tonnes; crude oil exports were 1.7 million tonnes, and oil products exports were 95.9 million tonnes. For comparison, China in 2017 imported 84.4 million tonnes of oil products and 422.1 million tonnes of crude oil. Japan in the same year imported 162.5 million tonnes of crude oil and 42.1 million tonnes of oil products (BP 2018: 25). It shows that North East Asian energy giants, China and Japan, though developing close energy trade with ASEAN states, possess their own oil refining capacities and are not heavily dependent on oil products imports from that sub-region.

Still, Singapore's pattern as a major oil hub in the region can help to formulate 'one price' policy for the integration of South East Asian energy markets. Energy trading conducted by Singapore could contribute to making the 'one price' possible for energy commodities in the united energy space of ASEAN countries, and also further including all the East Asian countries which also import energy products from Singapore. This country, an already established oil and oil products trading hub in the region, can expand its scope of trading to other energy commodities (natural gas, electricity), and play an important role in prevailing in facilitating energy trade in the region. This would accelerate regional energy markets integration by obtaining the rule of a single price for energy commodities in this united market (Youngho Chang 2014: 24-25).

$L N G$ trade is a sphere of trade with growing importance in the twenty-first century. On the whole, natural gas is an alternative to the world's rapidly depleting supply of oil. Like oil, natural gas can be relatively easily transported to destination ports either by pipelines or by tankers. Liquefied natural gas has been at the heart of natural gas revolution. LNG's global trade is set to increase by over 2 per cent each year for the next twenty years (Bhattacharya A. and Bhattacharya T. 2014: 72). The global 
LNG balance is shifting to Asia, not only to mature markets like Japan and South Korea but also to China, Thailand, India. Much of it will come from the Pacific basin, particularly Australia, Indonesia. Among East Asia, the LNG exporting nations are Brunei, Indonesia, and Malaysia. Speaking about natural gas situation in South East Asia, on the whole, it should be mentioned that apart from Indonesia, Malaysia, and Myanmar, the rest of the region's countries are net gas importers (Bhattacharya A. and Bhattacharya T. 2014: 73).

As for $L N G$ price, BP Global provides statistical data for 'Japan CIF' and 'Japan Korea Marker (JKM)'. According to this data, in the year of 2000 Japan CIF cost was 4.72 US dollars per million Btu (British thermal unit), it steadily rose then, in 2008 the price was 12.55 US dollars, in 2011 (after some decrease) - it was already 14.73 US dollars, in 2012 - 16.75 US dollars, in 2013 - 16.17 US dollars, in 2014 - 16.33 US dollars, in 2015 - 10.31 US dollars, in 2016 in decreased to 6.94 US dollars and in 2017 began rising once again (8.10 US dollars). As for JKM LNG prices, they are available only from 2009, and the periods of rising and decrease generally coincide with Japan CIF LNG: in 2009 JKM cost 5.28 US dollars per million Btu, in 2011 - 14.02 US dollars, in 2013 - 16.56 US dollars, in 2015 - 7.45 US dollars, in 2016 - 5.72 US dollars, and in 2017 - 7.13 US dollars (BP 2018: 33). We can make a conclusion that pricing was more affected maybe by the Fukushima Daichi nuclear accident in Japan in 2011 and then occurred prolonged nuclear crisis that resulted in enhancing Japan's need for the natural gas imports than by energy integration processes in the region.

In 2017 via pipeline Indonesia exported 8 billion cubic metres of natural gas (all to Malaysia and Singapore), Myanmar exported 11.5 billion cubic metres of natural gas (all to China and Thailand). In the same year of 2017 Brunei exported 9.1 billion cubic metres of LNG (5.1 billion to Japan, 2 billion to South Korea, 1.1 billion to Malaysia, 0.2 billion to China, 0.6 billion to Taiwan, 0.1 billion cubic metres to Thailand); Indonesia exported 21.7 billion cubic metres of LNG (8.9 billion to Japan, 4.9 billion to South Korea, 4.2 billion to China, 2.9 billion to Taiwan, 0.3 billion to Thailand); Malaysia exported 36.1 billion cubic metres of LNG (20.2 billion cubic metres to Japan, 5.8 billion to China, 5.1 billion to South Korea, 4.1 billion to Taiwan, 0.3 billion to Singapore, 0.4 billion to Thailand) (BP 2018: 34). These figures show that natural gas trade of South East Asian countries bears a very inter-regional character, highly favourable for the development of regional energy integration.

On the whole, energy resource trade between the East Asian countries has been developing in a stable and dynamic way; the well-arranged and developed mechanisms, economic and legal base of energy cooperation contributes to it to a significant extent.

\section{Regional Interstate Initiatives on Cooperation in Energy}

The ASEAN states have been developing the legal base of energy cooperation for a long time. We have studied the documentary base of the Association in this sphere dating from the 1980s up to the most recent ones. Table 1 presents structurally chronologically significant official documents which symbolize the important stages in the development of energy cooperation within the ASEAN space. 
The Legal Base of Energy Cooperation within ASEAN,

Table 1 1980s - 2000s.

\begin{tabular}{|c|c|c|}
\hline Date & Document & Key Content \\
\hline 1986 & $\begin{array}{l}\text { ASEAN Petroleum Securi- } \\
\text { ty Agreement }\end{array}$ & $\begin{array}{l}\text { Establishment of the ASEAN Emergency Petroleum Sharing } \\
\text { Scheme for crude oil/petroleum in times of shortage and } \\
\text { oversupply }\end{array}$ \\
\hline 1986 & $\begin{array}{l}\text { Agreement on ASEAN En- } \\
\text { ergy Cooperation }\end{array}$ & $\begin{array}{l}\text { The ASEAN Member countries agreed to cooperate in the } \\
\text { efficient development and use of all forms of energy (com- } \\
\text { mercial and non-commercial, renewable or non-renewables; } \\
\text { in energy planning, development, conservation, security of } \\
\text { energy supply; in training, exchange of information }\end{array}$ \\
\hline $\begin{array}{c}1995- \\
1999\end{array}$ & $\begin{array}{l}\text { ASEAN Medium-Term } \\
\text { Programme of Action on } \\
\text { Energy Cooperation }\end{array}$ & $\begin{array}{l}\text { Review of the Programme of Action for Enhancement of } \\
\text { ASEAN Cooperation in Energy of 1991. It aims at enhanced } \\
\text { energy cooperation in electricity, oil and gas, coal, new and } \\
\text { renewable sources of energy, issue of energy efficiency, di- } \\
\text { versification and conservation, energy and environment, en- } \\
\text { ergy policy and planning. Plans for strengthening intercon- } \\
\text { nection development leading to the realization of the } \\
\text { ASEAN Power Grid are announced }\end{array}$ \\
\hline 1995 & $\begin{array}{l}\text { Protocol Amending the } \\
\text { Agreement on ASEAN En- } \\
\text { ergy Cooperation (1986) }\end{array}$ & $\begin{array}{l}\text { Enhances the range of cooperation in energy, given changes } \\
\text { in the situation. Encourages private sector participation in re- } \\
\text { source investigation, exploration, assessment planning, de- } \\
\text { velopment; energy planning; technological research; energy } \\
\text { efficiency and conservation; environment; energy supply and } \\
\text { diversification; processing, handling, transport and distribu- } \\
\text { tion of energy; standardization of energy-related facilities; } \\
\text { safety programmes, energy security arrangements; promot- } \\
\text { ing a more conducive environment for commercial and in- } \\
\text { vestment opportunities in the energy sectors }\end{array}$ \\
\hline 1997 & $\begin{array}{l}\text { Protocol Amending the } \\
\text { Agreement on ASEAN En- } \\
\text { ergy Cooperation }\end{array}$ & \\
\hline 1998 & $\begin{array}{l}\text { Agreement on the Estab- } \\
\text { lishment of the ASEAN } \\
\text { Centre for Energy }\end{array}$ & $\begin{array}{l}\text { Centre as a catalyst for the economic growth and develop- } \\
\text { ment of the ASEAN region by initiating, coordinating, and } \\
\text { facilitating national, joint and collective activities on energy. }\end{array}$ \\
\hline 2002 & $\begin{array}{l}\text { The ASEAN Memorandum } \\
\text { of Understanding on the } \\
\text { Trans-ASEAN Gas }\end{array}$ & $\begin{array}{l}\text { Provides a broad framework for ASEAN Members to coop- } \\
\text { erate towards the realization of the TAGP (Trans-ASEAN } \\
\text { Gas Pipeline) Project to help ensure greater regional energy } \\
\text { security. }\end{array}$ \\
\hline- & $\begin{array}{l}\text { Memorandum of Under- } \\
\text { standing on the ASEAN } \\
\text { Power Grid }\end{array}$ & $\begin{array}{l}\text { Broadens framework to cooperate towards the development } \\
\text { of a common ASEAN policy on power interconnection and } \\
\text { trade, and realization of the ASEAN Power Grid to help en- } \\
\text { sure greater regional energy security and sustainability }\end{array}$ \\
\hline
\end{tabular}

Source: Composed from the data in Association of Southeast Asian Nations, www.asean.org.

The data in Table 1 shows the development of energy cooperation between ASEAN member states - how it was becoming more complex and diversified. That was due to the influence by internal (for instance, economic ties development inside ASEAN) as well as external factors (evolvement of global energy frameworks, exploration, and de- 
velopment of new energy sources, new challenges related to energy sphere, transportation of energy resources, etc.)

Since 1999, the Association has adopted several plans on the regional energy cooperation. Today, ASEAN Plan of Action for Energy Cooperation (APAEC) 2016-2025 is the main guideline. It should be mentioned that already the Plan 2004-2009 concluded aims for enhancing integration of the regional energy infrastructures. It consisted of a few sectoral plans of action and roadmaps related to the ASEAN Power Grid, TAGP (Trans-ASEAN Gas Pipeline), Energy Efficiency and Conservation, New and Renewable Sources of Energy and Regional Energy Policy and Planning. ASEAN Plan of Action for Energy Cooperation 2010-2015 contained 26 strategic projects of the Association in the following areas (ASEAN Centre for Energy 2018):

- ASEAN Power Grid;

- Trans-ASEAN Gas Pipeline;

- Coal and Clean Coal Technology (promote Intra-ASEAN coal trade and investment, etc.);

- Energy Efficiency and Conservation;

- Renewable Energy (to achieve the 15 per cent target share of RE in ASEAN power generation mix; develop ASEAN as a hub for renewable energy, etc.);

- Regional Energy Policy and Planning;

- Civilian Nuclear Energy (conduct capacity building among ASEAN member states; strengthen public information; institutional, legal and regulatory capacities on nuclear power generation).

The Plan 2010-2015 gave energy a significant meaning in the transformation of ASEAN into a stable, secure, prosperous, competitive and integrated economic community by 2015 . ASEAN's primary energy requirement was projected to triple between 2005 and 2030 (partly these predictions are due to the fact that already today the ASEAN economies are dynamically growing, and their increasing energy demands are formed by economic and demographic growth). The fact of appearance of competition among the ASEAN countries for available energy resources is admitted in the document.

As for the newest Plan 2016-2025, it stresses the importance of already implemented programmes. Thus, it focuses on multilateral electricity trading in order to accelerate the realization of the ASEAN Power Grid, enhancing gas connectivity by expanding the Trans-ASEAN Gas Pipeline to include LNG regasification terminals as well as promoting clean coal technologies (ASEAN Plan of Action... 2016-2025: 2). As before the Plan covers energy efficiency and conservation, renewable energy, regional energy policy planning and it also includes civilian nuclear energy development prospects.

Let us pay attention to the two major important projects, the implementation of which can make the prospects of creating united energy space in ASEAN territory more realistic and implement Trans-ASEAN Energy Network - ASEAN Power Grid (APG) and Trans-ASEAN Gas Pipeline. The first program was mandated in 1997 by the ASEAN heads of states/governments under the ASEAN Vision 2020 towards ensuring regional energy security and promoting the efficient utilization and sharing of resources. It is aimed at creating united power and energy infrastructure in order to stimu- 
late general economic growth and development of the region. Today, approximately 66 per cent of the ASEAN population has access to electricity. Regional electricity production grew at an average rate of 8 per cent a year from 1990 to 2005 and is projected to grow at 6.1 per cent annually in 2005-2030 (ASEAN Plan of Action... 2010-2015). Given this fact, the ASEAN member states plan to enhance electricity trade across borders, through integrating the national power grids. They expect that this measure will help to meet the rising electricity demand and improve access to energy services. It will also contribute to creating unified power and energy standards in South East Asian countries. To pursue the program, interconnections of 16 identified projects are planned, first on cross-border bilateral terms, then gradually expand to sub-regional basis and eventually to a totally integrated Southeast Asian power grid system. By now, 6 on-going interconnection projects have been completed and additional projects are planned for interconnection through the next years.

Interconnections under the ASEAN Power Grid Project:

Already existing lines:

- Sadao - Bekit Keteri, Khlong Ngae - Gurun, etc. (Thailand - Peninsular Malaysia)

- Roi Et 2 - Nam Theun 2, Sakon Nakhon 2 - Thakhek - Then Hinboun (Thailand - Lao PDR)

- Sarawak - West Kalimantan (began operating in January 2016)

Priority projects:

- Peninsular Malaysia - Sumatra (2020)

- Sarawak - Brunei (2018)

- Lao PDR - Cambodia (2017)

Other planned interconnections:

- P. Malaysia - Singapore (post-2020)

- Thailand - Malaysia

- Sarawak (east Malaysia) - Peninsular Malaysia (2025)

- Batam - Bintan (Indonesia) - Singapore (2020)

- Philippines - Sabah (Malaysia) (2020)

- Sarawak - Sabah - Brunei (2018-2010)

- Thailand - Myanmar (2018-2026)

- East Kalimantan - Sabah (post-2020)

- Lao PDR - Vietnam

- Vietnam - Cambodia

- Thailand - Cambodia (post-2020)

- Singapore - Sumatra (post-2020)

The ASEAN Power Grid program has made steady progress, mainly driven by bilateral power trade that comes with long-term power purchase agreements (PPAs). According to the Asian Development Bank estimations, before a really integrated ASEAN power market comes into being, this progress needs to cover the following four stages:

1. bilateral trade with PPAs; 
2. grid-to-grid power trading between any pairs of member countries; also using the transmission lines through a thirds member country;

3. development of transmission lines dedicated to free power trading instead of specific PPAs;

4. fully competitive regional market with multiple sellers and buyers from each member country.

It is evident that a significant amount of investment in these interconnections should be done. According to the ASEAN Plan of Action for Energy Cooperation, 2010-2015, the total investment of the ASEAN Power Grid which includes 15 projects, amounts to 5.9 billion dollars. Governments and intergovernmental organizations, such as the Asian Development Bank and the World Bank, could lead the early stage of developing the interconnected and integrated power markets, the next stages of investment in the infrastructure would need to engage more closely the private sector and private investors. So, investment in cross-border transmission lines should be commercially and financially viable and profitable for investors. (Li and Chang 2014: 164-165)

Another large-scale infrastructure project, Trans-ASEAN Gas Pipeline, - lies in the sphere of joint efforts in providing regional energy security. TAGP aims to interconnect existing and planned gas pipeline infrastructure within ASEAN, to transport gas across borders to ensure greater security of gas supply (ASEAN Plan of Action... 2016-2025: 21). In the long term, it is aimed at providing all the ASEAN states with energy resources, optimize their cooperation in oil and gas sphere. It aims to develop a regional gas grid by 2020, by linking the existing and planned gas pipeline networks of the subregion. In the 2010-2015 Plan, it was decided that it would involve the construction of 4,500 kilometers of pipelines mainly undersea, worth USD 7 billion. As of 2015, 13 bilateral gas pipeline interconnection projects connecting 6 countries and with a total length of about $3,673 \mathrm{~km}$ have been commissioned. They form part of the backbone of energy security and sustainability of gas supply in the region. They are:

- Malaysia - Singapore (5 km, 1991)

- Yadana (Myanmar) - Ratchaburi (Thailand) $(470 \mathrm{~km}, 999)$

- Yetagun (Myanmar) - Ratchaburi (Thailand) $(340 \mathrm{~km}, 2000)$

- West Natuna (Indonesia) - Singapore (660 km, 2001)

- West Natuna (Indonesia) - Duyong (Malaysia) (100 km, 2001)

- Malaysia/Vietnam Commercial Arrangement Area (CAA) - Malaysia (270 km, 2002)

- South Sumatra (Indonesia) - Singapore (470 km, 2003)

- Malaysia - Thailand Joint Development Area (JDA) - Malaysia via Songkla (270 km, 2005)

- Malaysia - Singapore (4 km, 2006)

- Malaysia/Vietnam CAA - Vietnam (330 km, 2007)

- Thailand/Malaysia JDA - Thailand (100 km, 2009)

- Zawtika Block M9, Myanmar - Thailand (302 km, 2013)

- Block 17 (Thailand/Malaysia JDA) to Kerteh, Terengganu, Malaysia (352 km, 2015) (ASEAN Plan of Action... 2016-2025: 22) 
These interconnections form part of the backbone of basic energy supply to which new lines will be added. Besides, preliminary studies on LNG cooperation within ASEAN are held, including studies on ship-shore compatibility, gas specification and LNG destination flexibility. The existing regasification terminals within ASEAN are located in Thailand, Indonesia, Singapore, and Malaysia.

There are a few organizations in the ASEAN framework which were created for the purpose of regulation and coordination by joint efforts of the energy situation in ASEAN. Along with the Centre for Energy, there is ASEAN Council on Petroleum (ASCOPE) - a regional structure established in 1975, in which member countries are represented by their national oil or energy companies. ASCOPE works on three largescale projects and initiatives: the above mentioned Trans-ASEAN Gas Pipeline Project, that is gradually taking its shape with new pipeline interconnections being added to the energy infrastructure of ASEAN countries. Other ASCOPE projects include Decommissioning Guideline for Oil and Gas Facilities and the new ASEAN Petroleum Security Agreement. The latter establishes the petroleum sharing scheme in case of petroleum supply shortages. It has been ratified by 8 ASEAN member states, excluding Indonesia and Cambodia. Practically it suggests stockpiling initiatives on a voluntary and commercial basis.

Energy officials of the ASEAN countries develop cooperation at various levels. Thus, meetings of the Heads of ASEAN Power Utilities are held. They address mainly projects in the areas of renewable energy, power interconnection, R\&D, geothermal energy, rural and urban electrification, use of combined cycle power plants, deregulation and reform of power utilities, etc. At the ASEAN Ministers on Energy meeting questions of strengthening multilateral ties are discussed, including those related to cooperation with Japan, China, and South Korea in order to address various issues in energy security, natural gas development, oil markets, oil stockpiling, and renewable energy. The 'ASEAN Plus Three' group was established. Among its urgent tasks is enhancing cooperation through energy infrastructure development, investment promotion, trading arrangements, and the application of new technologies.

Possibilities for cooperation in the energy sector, such as oil stockpiling, natural gas utilization, energy efficiency promotion, etc. are also studied by the ASEAN - Japan Framework for Comprehensive Economic Partnership. Japan is one of the official partner states of the ASEAN Centre for Energy, that serves a significant role in conducting regional energy programmes and activities.

\section{Problems and Possible Obstacles to Energy Integration in East Asia}

Research on energy market integration has been the focus of many scholars, researchers, and leaders in the energy field as evidences, particularly in Europe and America, tend to show the benefits from such market integration (Kimura and Han 2014: 1). As for energy integration in East Asia, and notably in ASEAN, it has some specific features to be taken into consideration. Firstly, some less economically developed countries of ASEAN may want to switch their close cooperation with the members of the ASEAN community to other neighbouring countries outside ASEAN that may show interest towards deepening their energy cooperation, Thus, with the emerging develop- 
ment of Myanmar and its general resource surplus, particularly on oil and gas, coupled with its strategic location to bridge South East Asia to South Asia, it can be suggested that cooperation between Myanmar and India (especially taking into consideration India's 'Look East Policy') will be beneficial for both countries in the long run. India shows a certain positive and active movement toward a joint gas field development, which can provide India better energy security in terms of having a cheaper gas supply. At the same time, Myanmar is interested in getting India's technology, joint development of technological knowledge and skills. India can also help Myanmar in developing its road, rail, and port facilities that can be used as energy resources transit channels. So this cooperation with India could help Myanmar financially, and also give India an opportunity to explore the ASEAN energy market (Bhattacharya A. and Bhattacharya T. 2014: 63-109). Such connectivity between India and Myanmar can result both in enhancing their energy trade potential but also can provide a new challenge for ASEAN energy integration.

Also, there are some risks to the future increase in energy trade between the ASEAN countries because of their own internal energy consumption growth. Thus, about 80 per cent of electricity produced in Thailand comes from natural gas. Natural gas used in Thailand comes from mainly three sources: 79 per cent from the Gulf of Thailand (but there are fears that it can run out of natural gas by 2020), 18 per cent from Myanmar, and 3 per cent imported as LNG from Indonesia, Nigeria, Peru, Qatar, Russia. There are also risks that Thailand would not be able to renew its gas contract with Myanmar which is to end by 2030, as Myanmar's own electricity consumption needs are also growing fast. Thailand is working on plans to import natural gas through a pipeline from Cambodia but these plans still lack certainty from both governments (Chea P. and Chea S. 2014: 203-204).

Speaking about the energy sphere related problems in the region, the territorial dispute in the South China Sea and energy-related conflict of interests should be mentioned. The island group of the Spratlys is located adjacent to Vietnam and extending nearly to the Philippines. It is an area of considerable strategic and economic importance. There are five major claimants to various groups of islands in the Spratlys: China, Vietnam, Taiwan, the Philippines, and Malaysia. Brunei also has a minor claim, and Indonesia is becoming involved as a result of its possession of the Natuna Islands which may form part of the sometimes vaguely formulated Chinese claim. China lays claims to sovereignty over the entire Spratlys archipelago. Vietnam also claims the entire group and occupies a number of the islands. The other claimants mostly try to limit their claims to the areas under their actual possession (Catley B. and Keliat M. 1997: 7). Roderick O'Brien in his work 'South China Sea Oil. Two Problems of Ownership and Development' writes that the territorial dispute mainly derives from unsettled seabed boundaries between the countries of the region (O'Brien 1977: 21). It is understood that each claimant perceives rich natural resources, especially the resources of oil and gas around the Spratlys. China's claims of sovereignty over the sea (and the sea is estimated to possess 11 billion barrels of untapped oil and 190 trillion cubic feet of natural gas) have antagonized Brunei, Indonesia, Malaysia, the Philippines, Taiwan. In 2016 the Permanent Court of Arbitration at the Hague issued the ruling on a claim brought by 
the Philippines against China ruling generally in favour of the Philippines. (Council on Foreign Relations 2018) So this dispute still goes on, it is related to the countries' intensions to expand their resource possessions but the confrontation mainly develops between China and the other states so it does not play a significant role in challenging energy integration in ASEAN.

\section{Conclusion}

Basing on the analysis made, we can state a relatively advanced stage of energy cooperation between the ASEAN members at the governmental level. The countries' governments through specialized organizations and mechanisms of the Association have worked out and implement projects and initiatives aimed at creating interconnections of energy infrastructure in order to facilitate in future effective distribution of energy resources between the South East Asian countries, solve urgent problems of energy efficiency, energy conservation, environment, fuel transportation and energy planning by joint effort. Today the ASEAN countries are not yet energy integrated but they are definitely moving in this direction, continuously and consciously forming common energy space. Japan, China, and South Korea participate in intergovernmental cooperation with ASEAN mainly in the framework of the 'ASEAN Plus Three'; generally they do not participate in the construction of interconnections in energy systems and pipeline interconnections with South East Asian neighbour countries.

The largest economies of East Asia, Japan, China and South Korea have advanced mechanisms and thus specific plans of energy integration neither between each other nor with ASEAN countries. Each of these North East Asian countries conducts mainly its own strategy in the energy sphere, aimed at fulfilling their own purposes of energy security and development. Nevertheless these states also have understanding that coordination of energy policies with other countries can be beneficial as it can contribute to regional energy security and solve energy problems in energy sphere which have surpassed national borders, but they cannot be managed effectively by one country, even if it is one of the leading economies in the world, and at the same time there are no existing global mechanisms for their effective regulation. Attempts to establish consulting mechanisms for the development of coordination in fuel energy complex of East Asian countries are taken, what can be regarded as a starting point if integration process at the level of intergovernmental initiatives in the energy sphere. For instance, in the 1990s, at the suggestion of Japan's Association for National Pipelines Systems Research North East Asia Forum on the problems of gas pipelines as a non-commercial organization for international cooperation was founded (Makovskaya 2007: 120).

The adduced data and conducted analysis prove the idea that it is possible and reasonable to expect the formation of common energy space in a certain group of countries in East Asia, notably - ASEAN member states. They have created really working mechanisms, have gained experience and have developed ties between business structures in the energy sphere, and have been moving purposively towards very close regional cooperation in energy. By the present moment, it has every opportunity to transform into regional energy integration in the foreseen future. 
Japan, China, and South Korea develop energy ties with the other East Asian states in various directions and levels, but given certain factors (for instance differences in sizes of economy and as a result in scale of energy demand and consumption, absence of supranational regulative frameworks and mechanisms, etc.) their way of regional energy cooperation development can be quite different from their South East Asian neighbour states.

\section{REFERENCES}

ASEAN Plan of Action... 2015. ASEAN Plan of Action for Energy Cooperation (APAEC) 2016-2025. Jakarta: ASEAN Centre for Energy. URL: http://www.aseanenergy.org/wpcontent/uploads/2015/12/HighRes-APAEC-online-version-final.pdf.

ASEAN Plan of Action... 2009. ASEAN Plan of Action for Energy Cooperation 2010-2015. Association of Southeast Asian Nations. URL: http://www.asean.org/wp-content/ uploads/images/archive/22675.pdf

Bhattacharya A., and Bhattacharya T. 2014. ASEAN-India Gas Cooperation: Redefining India's 'Look East' Policy with Myanmar. In Han, P., and Kimura, F. (eds.), Energy Market Integration on East Asia: Energy Trade, Cross Border Electricity, and Price Mechanism (pp. 63-109). Jakarta, Indonesia: Economic Research Institute for ASEAN and East Asia. URL: http://www.eria.org/RPR-FY2013-29.pdf. Accessed 20.06.2018.

BP Statistical Review... 2018. BP Statistical Review of World Energy. London: BP Statistical Review. URL: https://www.bp.com/content/dam/bp/en/corporate/pdf/energy-economics/ statistical-review/bp-stats-review-2018-full-report.pdf. Accessed 18.06.2018.

Catley, B., and Keliat, M. 1977. Spratlys: The Dispute in the South China Sea. Aldershot: Ashgate.

Chea, P., and Chea, S. 2014. Assessment of Power Trade Benefits from Hydropower Projects in Lower Mekong River Basin. In Han, P., and Kimura, F. (eds.), Energy Market Integration on East Asia: Energy Trade, Cross Border Electricity, and Price Mechanism (pp. 193-240). Jakarta, Indonesia: Economic Research Institute for ASEAN and East Asia. URL: http://www.eria.org/RPR-FY2013-29.pdf. Accessed 20.06.2018.

Council on Foreign Relations. 2018. Territorial Disputes in the South China Sea. Global Conflict Tracker, June 22. URL: https://www.cfr.org/interactives/global-conflicttracker\#!/conflict/territorial-disputes-in-the-south-china-sea. Accessed 24.06.2018.

Kimura, F., and Han, P. (eds.) 2014. Energy Market Integration in East Asia: Energy Trade, Cross Border Electricity, and Price Mechanism. Jakarta, Indonesia: Economic Research Institute for ASEAN and East Asia. URL: http://www.eria.org/RPR-FY2013-29.pdf. Accessed June 20, 2018.

Li, Yanfei, and Chang, Youngho. 2014. Infrastructure Investments for Power Trade and Transmission in ASEAN+2: Costs, Benefits, Long-Term Contracts, and Prioritised Development. In Han, P., and Kimura, F. (eds.), Energy Market Integration in East Asia: Energy Trade, Cross Border Electricity, and Price Mechanism (pp. 163-192). Jakarta, Indonesia: Economic Research Institute for ASEAN and East Asia. URL: http:// www.eria.org/RPR-FY2013-29.pdf. Accessed June 20, 2018.

Makovskaya, M. A. 2007. Energy Dialogue of Russia - East Asia: Prospects of Regional Integration and Coordination of Energy and Commodities Based Industries. In Torkunov, A. V., Voskresenskii, A. D. (eds.), Energy Aspects of International Relations and Security in East Asia (pp. 159-171). Moscow. Original in Russian (Маковская М. A. 
Энергодиалог Россия - Восточная Азия: Перспективы региональной интеграции и координации энерго-сырьевого комплекса. Энергетические измерения международных отношений и безопасности в Восточной Азии / Ред. Торкунов А. В., Воскресенский А. Д., с. 159-171. М.).

Miheev, V. V. 2007. Globalization of Energy Security and Regional Cooperation in NorthEast Asia. In Torkunov A. V., and Voskresenskiy A. D. (eds.), Energy Dimensions of International Relations and Security in East Asia (pp. 50-68). Moscow: MGIMO. Original in Russian (Михеев В. В. Глобализация энергетической безопасности и региональное взаимодействие в Северо-Восточной Азии. Энергетические измерения международных отношений и безопасности в Восточной Азии / Ред. Торкунов А. В., Воскресенский А. Д., с. 50-68. М.: МГИМО).

Mishchenko, Y. 2012. Prospects of Energy Integration in Asia. Mezhdunarodnaya ekonomika 5: 29-36. Original in Russian (Мищенко Я. Перспективы энергетической интеграции в Восточной Азии. Международная экономика 5: 29-36).

O'Brien, R. 1977. South China Sea Oil. Two Problems of Ownership and Development. Paper no 47. Singapore: Institute of Southeast Asian Studies.

Youngho, Chang. 2014. Energy Commodity Trading in Singapore. Energy Market Integration in East Asia: Energy Trade, Cross Border Electricity, and Price Mechanism (pp. 13-26). Economic Research Institute for ASEAN and East Asia (ERIA). URL: http://www.eria.org/RPR-FY2013-29.pdf. Accessed June 20, 2018. 